
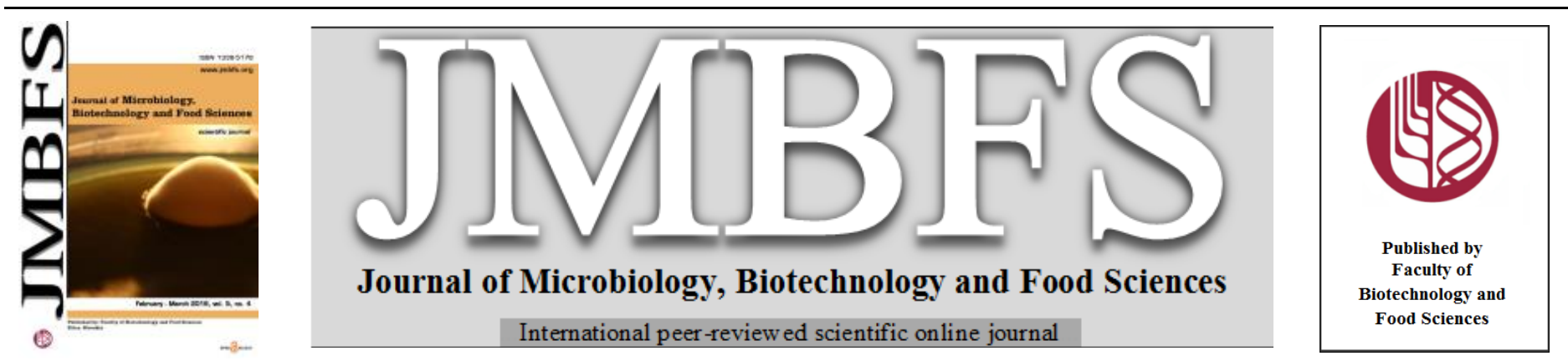

\title{
ISOLATION AND IDENTIFICATION OF DOMINANT LACTIC ACID BACTERIA FROM DAHI: AN INDIGENOUS DAIRY PRODUCT OF NEPAL HIMALAYAS
}

\author{
Rewati Raman Bhattarai ${ }^{*}$, Nawaraj Gautam ${ }^{2,3}$, Malik Adil Nawaz ${ }^{4}$, Suman Kumar Lal Das ${ }^{5}$ \\ Address(es): Rewati Raman Bhattarai, \\ phone number: +61416502002 . \\ ${ }^{2}$ Faculty of Mathematics and Natural Science, University of Bergen, NO - 5020 Bergen, Norway. \\ ${ }^{3}$ National Institute of Nutrition and Seafood Research, Nordnes 5817, Bergen, Norway. \\ ${ }^{4}$ School of Agriculture and Food Sciences, The University of Queensland, St Lucia, Qld 4072, Australia. \\ ${ }^{5}$ Tribhuvan University, Institute of Science and Technology, Central Campus of Technology, Hattisar, Dharan, Nepal.
}

${ }^{1}$ Centre for Nutrition and Food Sciences, Queensland Alliance for Agriculture and Food Innovation, The University of Queensland, St Lucia, Qld 4072, Australia,

*Corresponding author: r.bhattarai@uq.edu.au

doi: 10.15414/jmbfs.2016.5.4.358-363

\section{ARTICLE INFO}

Received 10. 3. 2015

Revised 14. 8. 2015

Accepted 25. 11.2015

Published 1. 2. 2016

Regular article

OPEN $\partial_{\text {ACCESS }}$

\begin{abstract}
Morphological, cultural, physiological and biochemical characteristics were employed to identify dominant Lactic acid bacteria (LAB) isolates from 39 dahi (indigenous dairy product) samples collected from different districts of eastern Nepal. The isolates comprised of predominately Lactobacillus fermentum, Lactobacillus delbrueckii subsp. bulgaricus, Streptococcus thermophilus, Lactococcus lactis subspecies cremoris, Lactococcus lactis subsp. lactis biovar diacetylactis and Leuconostoc mesenteroids subsp. mesenteroids. S. thermophilus were found consistently in most of the samples examined. In this study, 59.38\% of Lactobacilli, $21 \%$ of Streptococci, 8.2 $\%$ Lactococci and $11.42 \%$ Leuconostocs were isolated from indigenous dahi. This study revealed diversity of lactic acid bacteria in Nepalese milieu having immense potential in producing qualitative fermented milk.
\end{abstract}

Keywords: Isolation, Characterization, LAB, fermented dairy product, dahi

\section{INTRODUCTION}

Fermentation is one of the ancient food processing and preserving techniques used all around the world. There are many indigenous fermented foods from different regions. Dahi or curd is one of the popular fermented dairy products from South Asia. It is prepared from boiled milk, fermented in a traditional way by natural micro flora (Bhattarai and Das, 2013). Traditionally, dahi is consumed as a dessert or refreshing beverage along with main course in different rituals (Kharel et al., 2010). In Nepal, it has been consumed with boiled rice or "chewra" (rice flakes) (Dewan and Tamang, 2007) or use it to make as lassi (popular, traditional, yogurt-based drink) and dahi-wada (dish consisting of balls made from ground lentils, deep-fried and served in a yogurt sauce) (Bhattarai and Das, 2013). Fermentating milk to dahi itself is a primary step for other indigenous dairy products like nauni (Nepalese traditional butter), ghee (traditional clarified butter), mohi (traditional butter milk) and chhurpi (traditional hard cheese).

As much as $45 \%$ of total milk production is fermented into dahi in Eastern Nepal (Bhattarai and Das, 2013). In Nepalese indigenous way, dahi is fermented in theki (a wooden utensil) made from daar (Boehmeria rugulosa) wood. Main purpose of daar theki is believed to give unique flavor in dahi (Bhattarai and Das, 2013) and might serve as natural micro flora reservoir. Flavor chemistry and microbial role are major subjects of interest in dahi. Microbiology and diversity have been studied by some researcher in indigenous dairy products from different parts of world. Knowledge on microbial diversity of various indigenous foods can guide us in to different arena. Typical microbial species and strains from indigenous food origin could be used to make starter culture or other industrial product. Among many important species, groups of Lactic Acid Bacteria (LAB) are vital and natural micro flora in different foods due to their unique fermentation mechanism (Gilliland, 1990) relating to their health and nutritional benefits (Francois et al., 2007). LAB isolation from fermented milks have been practiced to screen desirable traits so as to obtain consistent quality, high productivity and safety (Erkuș, 2007).

Isolation of microbial strains from ready to eat food products helps in maintaining the food safety standards in food industries (Nawaz and Bhattarai, 2015). Identification and characterization of $L A B$ in various indigenous foods from different parts of the world have been reported, for example: rob of Sudan
(Abdelgadir et al., 2001; Abdalla and Hussain, 2010), rayeb of Egypt (Al Rubayyi et al., 2010), amasi of Zimbabwe (Gran et al., 2003), Fulani of Burkina Faso (Savadogo et al., 2004), kulenaoto of Kenya (Mathala et al., 2004), laban of Lebanon (Chammas $\boldsymbol{e t}$ al., 2006), nyarmie of Ghana (Obodai $\boldsymbol{e}$ al., 2005), fermented milk from the Romania (Zamfir et al., 2006), Tibet (Airidengcaicike et al., 2010) and Mongolia (Oki et al., 2014). Very limited studies have been reported on microbial diversity and safety on Nepalese fermented milk products. This paper is therefore aimed at isolating and identifying lactic acid bacteria associated with indigenous dahi from eastern Nepal.

\section{MATERIAL AND METHODS}

\section{Collection of samples}

Thirty nine indigenous dahi samples were collected from sixteen districts of eastern Nepal. Preliminary study was done to confirm the highly dense dahi producing locations in different districts. No specific permissions were required for sample collection in these areas as local people were helpful and were enthusiastic to understand the quality and microbial flora of indigenous dahi. The samples were aseptically collected in sterile screw capped test tubes using sterile latex gloves and kept cool in ice-box until taken to the food microbiology laboratory at Central Campus of Technology, Dharan, Nepal. Samples were kept below $4^{\circ} \mathrm{C}$ for further use and examinations. No human or animals were used in the experiments as well as the field studies did not involve endangered or protected species.

\section{Isolation of Lactobacilli, Lactococci, Leuconostoc, and Streptococci}

Twenty five grams of dahi samples were homogenized with $225 \mathrm{~mL}$ Quarter Strength Ringer's solution to make an initial dilution $\left(10^{-1}\right)$ and decimal dilution techniques were applied according to Public Health England (2014). Aliquots with various dilutions amounting $0.1 \mathrm{~mL}$ were spread plated onto duplicate of different media plates (MRS agar, SL agar and D agar). MRS agar (Himedia, Mumbai, India) plates were incubated under anaerobic condition in an Anaerobic Gas-Pack system (Himedia, Mumbai, India) at $30^{\circ} \mathrm{C}$ for $48-72 \mathrm{~h}$ to isolate 
Lactobacilli (Badis et al., 2004a); Streptococcus lactis differential agar plates (SL) (Himedia, Mumbai, India) were incubated at $37^{\circ} \mathrm{C}$ for $48 \mathrm{~h}$ to differentiate citrate utilizing and non-utilizing Lactococci (Kempler, Mckay, 1980); MRSvanomycin (vanomycin $20 \mathrm{mg} . \mathrm{L}^{-1}$ ) plates were incubated at $30^{\circ} \mathrm{C}$ for $24 \mathrm{~h}$ to isolate Leuconostoc (Mathot et al., 1994); differential agar mediums (D) were incubated at $32^{\circ} \mathrm{C}$ for $48 \mathrm{~h}$ to differentiate $S$. lactis and S. cremoris (Reddy et al. 1969) and $S$. thermophilus (ST) agar plates with added cycloheximide (100 mg. $\mathrm{L}^{-1}$ ) for inhibition of yeast growth (Beukes $\boldsymbol{e t}$ al., 2001) were incubated at $42^{\circ} \mathrm{C}$ for $24-48 \mathrm{~h}$ to isolate Streptococci (Atlas, 2004). Colonies were selected randomly from agar plate. If the plate contained less than 10 colonies, all colonies were isolated. Purity of the isolates were checked by streaking again and sub-culturing on fresh media plates, followed by microscopic examinations. Isolated strains of Lactobacilli and Streptococci were preserved in MRS and ST broth at $-20^{\circ} \mathrm{C}$. Purified strains of Lactococci and Leuconostoc were preserved subsequently on the same media through periodic transfer.

\section{Identification of the bacterial strains}

Those preserved isolated strains were tested for gram staining, catalase production and spore formation by method from Harrigan and McCance (1976). Hydrolysis of arginine, citrate utilizations, gas formations from glucose in MRS broths containing inverted Durham tubes, dextran productions from sucrose in MRS+ST agar, growths on different temperature $\left(10,37\right.$ and $\left.45^{\circ} \mathrm{C}\right)$ for 5 days, resistance to $60^{\circ} \mathrm{C}$ for $30 \mathrm{~min}$ (Sherman test), growths in the presence of 4 and $6.5 \%(\mathrm{w} / \mathrm{v}) \mathrm{NaCl}$ and different $\mathrm{pH}(4.5$ and 6.5) and changes in turbidity of MRS broth after 24, 48 and $72 \mathrm{~h}$ of incubations were implicated to identify the strains (Mayeux et al., 1962; Sharpe, 1979; Samelis et al., 1994;). Arginine MRS medium and Nessler reagent were employed to perform the hydrolysis tests as described by Yavuzdurmaz (2007). Citrate utilization and colored colonies growth were observed in SL and D agars and results were interpreted according to Reddy et al. (1969) and Kempler and Mckay (1980).

\section{Sugar fermentation tests}

Membrane $(0.45 \mu \mathrm{m})$ filtered $1 \%(\mathrm{w} / \mathrm{v})$ solutions of different sugars (glucose, fructose, lactose, galactose, maltose and mannitol) were deployed to study fermentation characteristics of the isolates. Nutrient broth $(0.8 \%)$ with $1 \mathrm{~mL}$ phenol red was autoclaved at $121 \pm 1^{\circ} \mathrm{C}$ for 15 minutes then cooled to room temperature. Five $\mathrm{ml}$ of broth and $100 \mu \mathrm{L}$ of sugars were taken into sterilized test tubes. These tubes were checked for contamination by placing at room temperature for 24 hours. After 24 hours, the purified colonies were inoculated into test tubes with specific sugar containing broth and incubated at $37^{\circ} \mathrm{C}$ for 48 hours. The positive test for sugar fermentation was indicated by color change from red to yellow in the test tubes as mentioned by Mehmood et al. (2009).

\section{RESULTS AND DISCUSSION}

\section{Isolation and characterization of thermophilic LAB}

Isolation and characterization of thermophilic LAB is highly desirable for dairy manufacturing as the selective species are used as starter cultures. Lactobacilli and Streptococci isolates characterized and counted are presented in Figure 1. Mean counts of all Lactobacilli were $133 \times 10^{6} \mathrm{cfu}^{-1} \mathrm{~g}^{-1}$ representing $59.38 \%$ and Streptococci were $47 \times 10^{6} \mathrm{cfu}^{-1} \mathrm{~g}^{-1}$ representing $21 \%$ of total isolates from dahi samples. The isolated Lactobacilli were further characterized into different species based on their physiological and biochemical properties (Table 1). In most of our indigenous collected dahi samples, Lactobacilli were dominant bacilli and S. thermophilus were dominant cocci. These findings are according to previous one on Mongolian fermented dairy product where Lactobacilli are dominant (Oki et al., 2014). S. thermophilus plays major roles in the coagulation of milk and is responsible for the production of dahi and its quality. Predominant role of Lactobacilli and Streptococci in the indigenous sample from eastern Nepal were somewhat different from some previous results for fermented milks from different origination (Baldorj et al., 2003; Mathara et al., 2004; Xiao et al., 2004, Harun-ur-Rashid et al., 2007, Watanabe et al., 2008, Yu et al., 2011). Not always Lactobacillus and Streptococcus are dominant in all traditiona fermented dairy products such as Leuconostoc are dominant over Lactobacillus South African fermented milk (Beukes et al., 2001). On the other hand, $S$. thermophilus are important in Greek feta cheese (Manolopoulou et al., 2003), in traditional Ugandan beverage bushera (Muyanja et al., 2003) and commercial Nigerian bottled yoghurt (Omafuvbe et al., 2011). While, dahi from Bangladesh could be considered different in terms of dominant $S$. bovis instead of $S$. thermophilus (Harun-ur-Rashid et al., 2007) than dahi from eastern Nepal.

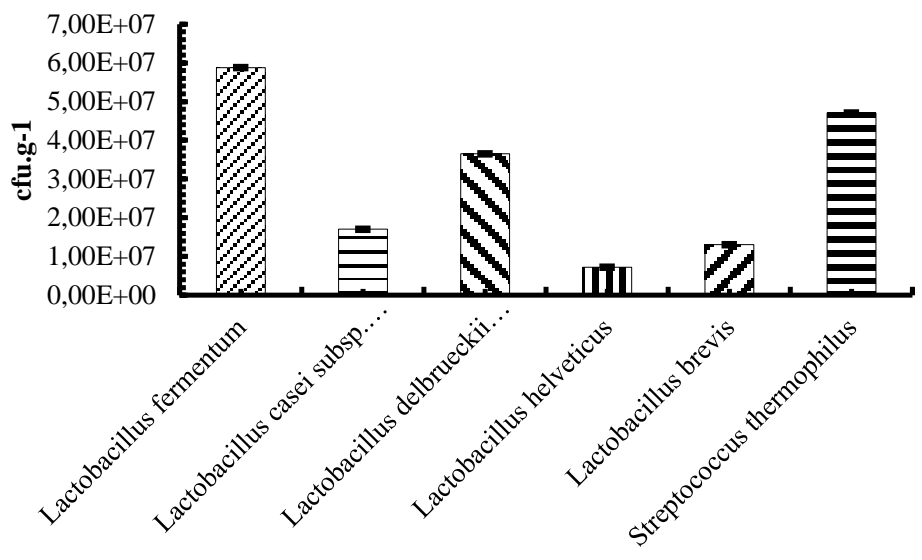

Isolated strains

Figure 1 Mean counts (cfu.g ${ }^{-1}$ ) of isolated strains of thermophilic lab found in dahi samples obtained from different districts of eastern Nepal

LAB are omnipresent in dairy products. Physiological and biochemical characteristics of isolated LAB strains from dahi of eastern Nepal were done (Table 1). Presence of different Lactobacilli species in dahi samples from Eastern Nepal can be explained by presence of these bacteria as natural micro flora in raw milk sources. To produce different dairy product, it is important to use specific fermentation methodology along with natural micro flora and desired fastidious species such as $L$. delbrueckii subsp. bulgaricus, $L$. helveticus etc. $L$.helveticus has been major contributor in starter cultures of some cheese like Gruyere, Gorgonzola and Mozzarella (Tserovska et al., 2002). This can be explained as the different strains are indigenous micro biota to milk from different animal sources. Raw milk from four races of Algerian goat was abundant of $L$. helveticus and L. delbrueckii subsp. bulgaricus (Badis et al., 2004b). Other Lactobacilli species like L. plantarum, L. brevis and L. delbrueckii subsp. bulgaricus are isolated from bushera (Muyanja et al., 2003) and L. delbrueckii subsp. bulgaricus from South African traditional fermented milk (Beukes et al., 2001).

Table 1 Physiological and biochemical characteristic of isolated thermophilic strains from different districts of Eastern Nepal.

\begin{tabular}{|c|c|c|c|c|c|c|}
\hline $\begin{array}{l}\text { Characteristics Of The } \\
\text { Strains }\end{array}$ & L. fermentum & L. casei subsp. casei & $\begin{array}{c}\text { L. delbrueckii subsp. } \\
\text { bulgaricus }\end{array}$ & L. helveticus & L. brevis & S. thermophilus \\
\hline Gram Strain Reaction & + & + & + & + & + & + \\
\hline Catalase Activity & - & - & - & - & - & - \\
\hline Glucose Fermentation & + & + & - & + & + & - \\
\hline $\mathrm{NH}_{3}$ From Arginine & - & - & - & - & + & - \\
\hline \multicolumn{7}{|c|}{ Growth At Temperature ${ }^{\circ} \mathrm{C}$} \\
\hline 10 & - & - & + & - & + & - \\
\hline 37 & $\mathrm{~V}$ & - & + & + & - & + \\
\hline 45 & + & - & + & + & - & + \\
\hline \multicolumn{7}{|c|}{$\begin{array}{l}\text { Growth in a Medium With } \\
\mathrm{NaCl}, \%\end{array}$} \\
\hline 4 & + & + & - & + & - & - \\
\hline 6.5 & - & - & - & + & - & - \\
\hline \multicolumn{7}{|l|}{ Growth at pH } \\
\hline 4.5 & - & + & + & + & + & - \\
\hline 6.5 & + & + & + & - & + & + \\
\hline
\end{tabular}




\begin{tabular}{|c|c|c|c|c|c|c|}
\hline $\begin{array}{l}\text { Production Of } \mathrm{CO}_{2} \text { from } \\
\text { Glucose }\end{array}$ & + & - & - & - & + & - \\
\hline Dextran Production & - & - & - & - & - & $\mathrm{V}$ \\
\hline Citrate Utilization & - & - & - & - & - & - \\
\hline $\begin{array}{l}\text { Heat Resistance at } 60{ }^{\circ} \mathrm{C} \text { for } 30 \\
\text { min }\end{array}$ & - & - & - & + & - & + \\
\hline \multicolumn{7}{|l|}{ Sugar fermentation tests } \\
\hline Fructose & + & + & + & - & + & + \\
\hline Galactose & + & + & - & + & + & - \\
\hline Glucose & + & + & - & + & + & + \\
\hline Lactose & + & + & + & + & + & + \\
\hline Maltose & - & + & - & - & $\mathrm{V}$ & - \\
\hline Sucrose & + & + & - & - & + & + \\
\hline Mannitol & - & + & - & - & + & - \\
\hline
\end{tabular}

Legend: $\mathrm{V}=$ Variable.

In Tibetan traditional fermented milk $71.3 \%$ bacilli and $28.7 \%$ cocci have been screened and two species $L$. fermentum and $L$. casei are predominant along with variation between different regions (Airidengcaicike et al., 2010). This could be due to the fact that, micro flora in dairy products is affected by the climatic and other external factors like altitude. In cold climatic regions mesophilic organisms such as Lactococcus and Leuconostoc have been found to be dominant in fermented milk products while thermophilic bacteria such as Lactobacillus and Streptococcus in warm regions as explained by Kurman (1984). Differences in the profile of LAB flora in our study as compared to previous findings could be attributed to variations in the specific environmental conditions found in Himalayan region specifically in eastern Nepal. The altitude is considered as one of the important factors that influenced the climate and then temperature variations in the different parts of Nepal. Eastern Nepal is divided into three zones, namely, Mechi, Koshi and Sagarmatha ranging from plain terai to Mt. Everest. Moreover, cold climatic zone in upper Himalayan area and hilly area and hot climatic terai have a significant role in the natural micro flora statistics. The environmental factors, such as dry climate, low temperature, scant oxygen, low atmospheric pressure, strong sunlight and long sunlight radiation in Himalayas may also contribute to these variations. This present findings are according to previous findings on different fermented dairy product from Mongolia (Oki $\boldsymbol{e} t$ al., 2014), Kenya (Mathala et al., 2004), Nigeria (Olasupo et al., 2001) and Bangladesh in terms of L. fermentum. It has also been doubted on the negative role of $L$. fermentum as weak coagulant, gas producer giving bad texture and taste in dairy products (Harun-ur-Rashid et al., 2007). In addition, this bacterium has been connected to many potential probiotic properties, such as acid resistance, bile salt tolerance and indigestible carbohydrate degradation (Airidengcaicike $\boldsymbol{e} t$ al., 2010). Therefore, these strains required to be evaluated for probiotic applications and commercialization of indigenous dahi

Isolation and characterization of Lactococci

Lactococci species contribute to more subtle aromas and flavor that distinguish the fermented dairy products. Gram positive, catalase negative and non-spore forming isolates were isolated from 39 different samples using SL and D agars. These were further characterized as mesophilic homo-fermentative cocci. The counts of these isolates were as presented in Figure 2. Total $7.282 \times 10^{6} \pm 45.19$ cfu. $\mathrm{g}^{-1}$ of L. lactis subsp. lactis biovar. diacetylactis, $2.221 \times 10^{6} \pm 13.84 \mathrm{cfu}^{6} \mathrm{~g}^{-1}$ of L. lactis subsp. lactis and $9.05 \times 10^{6} \pm 5.61 \mathrm{cfu}^{-1}{ }^{-1}$ L. lactis subsp. cremoris were isolated from dahi samples of eastern Nepal. These groups $\mathrm{ADH}^{-1}$ (arginine dihydrolase - negative arginine hydrolysis), citrate $^{-1}$ (negative citrate utilization) isolates from dahi sample were further identified as L. lactis subsp. cremoris and L. lactis subsp. lactis biovar. diacetylactis by physiological and biochemical characteristics (Table 2). Isolated LAB were spherical or ovoid in shape, nonmotile and occurred in pairs.

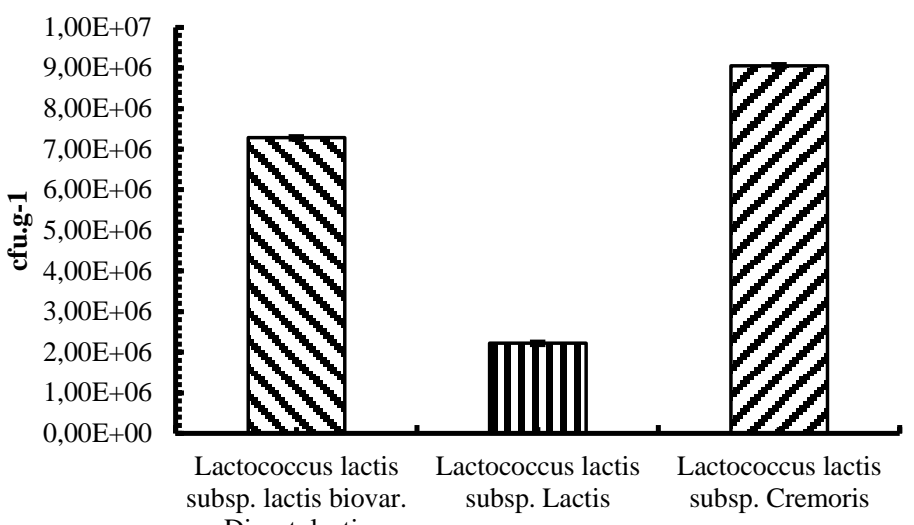

Diacetylactis

Isolated strains

Figure 2 Mean log counts $\left(\mathrm{cfug}^{-1}\right)$ of isolated strains of lactococcci found in dahi samples obtained from different districts of eastern Nepal

These findings are accordance with some previous findings reported on isolation of L. lactis subsp. lactis, L. lactis subsp. cremoris from dahi of Himalayas (Dewan, Tamang, 2007) and L. lactis subsp. cremoris from Kazerun's traditional fermented yoghurt (Azadnia et al., 2011). Similarly, L. lactis are abundant in South African fermented milks (Beukes et al., 2001) and Algerian goat milk (Badis et al., 2004b). On the other hand, lactic acid cocci were found to be low in number as compared to lactic acid bacilli in the mixed culture. Low numbered lacto cocci than lacto bacilli might be due to inability to cope with bacilli in dahi fermentation as explained by Azadnia et al. (2011). The present study was executed to design the production of LAB starter culture. Activities of Lactococcus spp. are found in such a way that it might be possible to produce dahi consistently in quality from each batch, with its unique typical indigenous texture and flavor. In future, it might lead through the genetic characterization and selection of the most desirable strains giving highly pure commercialized strain to further elaborate the industrialization of local product.

Table 2 Physiological and biochemical characteristic of isolated Lactococci strains from different districts of Eastern Nepal.

\begin{tabular}{|c|c|c|c|}
\hline Characteristice Of The Strains & $\begin{array}{c}\text { Results for L. lactis subsp. lactis biovar. } \\
\text { Diacetylactis }\end{array}$ & $\begin{array}{l}\text { Results for L. lactis subsp. } \\
\text { lactis }\end{array}$ & $\begin{array}{l}\text { Results for } L \text {. lactis subsp. } \\
\text { cremoris }\end{array}$ \\
\hline Gram Strain Reaction & + & + & + \\
\hline Catalase Activity & - & - & - \\
\hline Glucose Fermentation & + & + & + \\
\hline $\mathrm{NH}_{3}$ From Arginine & + & $+/-$ & - \\
\hline
\end{tabular}

\section{Growth At Temperature ${ }^{\circ} \mathrm{C}$}

10

37

45

$+$

$++$

\section{Growth in a Medium With NaCl, \%} 4

6.5

\section{Growth at pH}




\begin{tabular}{|c|c|c|c|}
\hline Dextran Production & $\mathrm{V}$ & $\mathrm{V}$ & $\mathrm{V}$ \\
\hline Citrate Utilization & + & - & - \\
\hline \multicolumn{4}{|c|}{ Sugar fermentation tests } \\
\hline Fructose & - & - & - \\
\hline Galactose & - & + & - \\
\hline Glucose & + & + & + \\
\hline Lactose & + & + & + \\
\hline Maltose & - & + & - \\
\hline
\end{tabular}

\section{Mannitol}

\section{Legend: V=Variable.}

Isolates were divided into two subgroups and a biovar. on the basis of growth pattern in SL and D agar. In SL agar, two different colored colonies were obtained. One colony was white and other Prussian blue. Totally white colonies in $48 \mathrm{~h}$ were identified as $S$. lactis and S. cremoris. Prussian blue colonies were identified as S. lactis subsp. lactis biovar. diacetylactis. In D agar, three different colored colonies were obtained. First types were white colonies, second yellow with yellow zones and last ones were Prussian blue. White colonies were identified as $S$. lactis, yellow colonies as $S$. cremoris and Prussian blue as $S$. lactis biovar. diacetylactis. The former produced small yellow colonies with yellow zones and the latter produced larger white colonies with no surrounding zones on the finalized medium. It has been justified by evident coloration in extended incubation time as explained in one of the previous studies by Reddy $\boldsymbol{e} t$ al. (1969). Occasional variability in the shade or amount of blue color on colonies was recorded with some $S$. diacetylactis strains. This might be due to natural variability on citrate transportation. However, all citrate-positive colonies were blue or large blue centered. Rapid citrate accumulation could be the reason for blue coloration of colonies and this citrate might be utilized by $S$. diacetilactis.

\section{Isolation and characterization of Leuconostoc}

The presence of leuconostoc species in fermented milk is highly desirable as it would relate to the flavorful fermented products. All grams positive, catalase negative and non-spore forming isolates were further characterized as mesophilic hetero-fermentative cocci using MRS-vancomycin media. The count of these isolates is shown in figure 3. A total of $5.789 \times 10^{6} \pm 14.12 \mathrm{cfu}^{-1} \mathrm{~g}^{-1}$ of Leuconostoc mesenteroides subsp. cremoris, and $21.99 \times 10^{6} \pm 25.70 \mathrm{cfu}^{-1} \mathrm{~g}^{-1}$ of $L$. mesenteroides subsp. mesenteroids were isolated from indigenous dahi. These bacteria represented a reduced fermentative profile, unable to hydrolyze arginine, producing gas from glucose with citrate $+/$ - and dextran negative reactions. Physiological and biochemical characteristic of isolated strains from dahi samples were tested and results are presented in table 3 .

Mean counts $\left(\mathrm{cfug}^{-1}\right)$ of isolated strains found in dahi samples obtained from different districts of eastern Nepal.

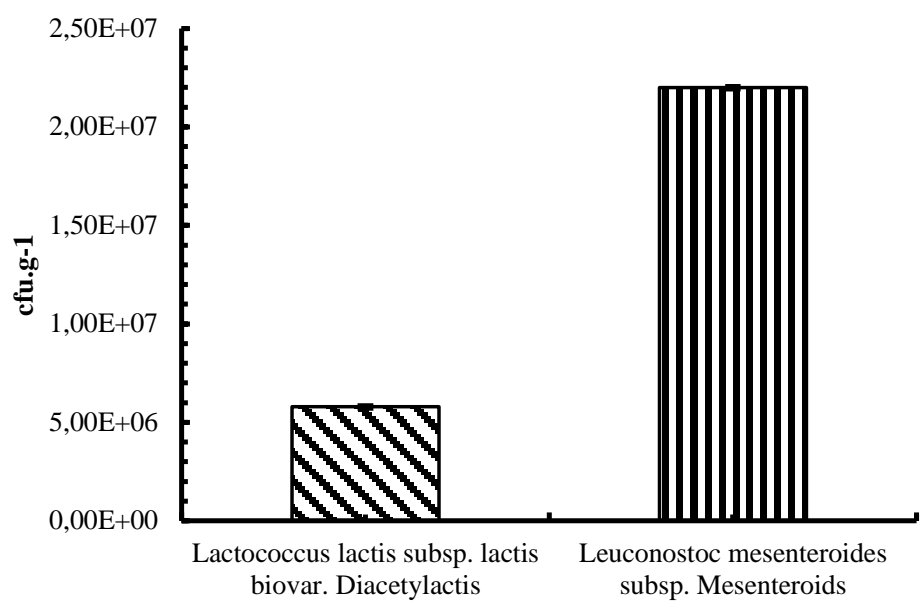

Isolated strains

Figure 3 Mean counts $\left(\mathrm{cfug}^{-1}\right)$ of isolated strains of leuconostoc found in dahi samples obtained from different districts of eastern Nepal

These micro-aerophilic organisms were also characterized by the fermentation metabolism of fructose, galactose, glucose, lactose, maltose, sucrose and mannitol. L. mesenteroides subsp .cremoris was fructose, maltose and mannitol negative whereas $L$. mesenteroides subsp. mesenteroids were negative to mannitol only. The former utilized citrate while the latter did not (Table 3). $L$. cremoris and $L$. mesenteroides are Arginine hydrolyser and these might be present in dahi. Arginine hydrolysis and citrate utilization methods were tested to differentiate $L$. mesenteroides and $L$. cremoris. Arabinose fermentation was also implemented to confirm species. $L$. mesenteroides subsp. cremoris and $L$. mesenteroides subsp. mesenteroids were isolated from 39 samples but low in counts. Low numbers of these lactic acid cocci might be due to their inability to compete over lactic acid bacilli in mixed cultures. The low percentage of Leuconostoc strains isolated from indigenous dahi samples could partly be explained by their complex nutritional requirements and lower adaptation (Azadnia et al., 2011) to dairy products. Leuconostoc plays important role in flavor development in dairy products (Mataragas et al., 2004) and unique flavor in dahi might be attributed to this micro flora in some instances but need to do further detail study on flavor development aspects of this indigenous dairy products from Himalayas.

Table 3 Physiological and biochemical characteristic of isolated Leuconostoc strains from different districts of Eastern Nepal. V=Variable.

\begin{tabular}{|c|c|c|}
\hline Characteristice Of The Strains & Results for L. mesenteroides subsp. cremoris & Results for L. mesenteroides subsp. mesenteroids \\
\hline Gram Strain Reaction & + & + \\
\hline Catalase Activity & - & - \\
\hline Glucose Fermentation & + & + \\
\hline $\mathrm{NH}_{3}$ From Arginine & - & - \\
\hline \multicolumn{3}{|l|}{ Growth At Temperature ${ }^{\circ} \mathrm{C}$} \\
\hline 10 & + & + \\
\hline 37 & $\mathrm{~V}$ & + \\
\hline 45 & - & - \\
\hline \multicolumn{3}{|c|}{ Growth in a Medium With $\mathrm{NaCl}, \%$} \\
\hline 4 & - & - \\
\hline 6.5 & V & - \\
\hline \multicolumn{3}{|l|}{ Growth at pH } \\
\hline 4.5 & - & - \\
\hline 6.5 & + & + \\
\hline
\end{tabular}




\begin{tabular}{|c|c|c|}
\hline Production Of $\mathrm{CO}_{2}$ from Glucose & + & + \\
\hline Dextran Production & - & $\mathrm{V}$ \\
\hline Citrate Utilization & + & - \\
\hline Heat Resistance at $60^{\circ} \mathrm{C}$ for $30 \mathrm{~min}$ & - & - \\
\hline \multicolumn{3}{|l|}{ Sugar fermentation tests } \\
\hline Fructose & - & + \\
\hline Galactose & + & + \\
\hline Glucose & + & + \\
\hline Lactose & + & + \\
\hline Maltose & - & + \\
\hline Sucrose & $\mathrm{V}$ & + \\
\hline Mannitol & - & - \\
\hline
\end{tabular}

Legend: V=Variable.

Presence of $L$. mesentereroides in dahi samples in such numbers is somehow accordance with previous finding in indigenous fermented dairy products from Kenya (Mathara et al., 2004), Tibet of China (Airidengcaicike et al., 2010), South Africa (Beukes et al., 2001), Bangladesh (Harun-ur-Rashid et al., 2007), Uganda (Muyanja et al., 2003), Sudan (Ali, 2011). In this context, we can say that the $L$. mesenteroids are present in most indigenous milk derived products, either from Himalayas or other part of the world.

\section{Total LAB count in indigenous dahi of eastern Nepal}

The total LAB counts in indigenous dahi of eastern Nepal were found in the range from $221 \times 10^{6}$ to $225 \times 10^{6} \mathrm{cfu}^{-\mathrm{g}^{-1}}$. Mean LAB counts were $224 \pm 1.49 \times 10^{6} \mathrm{cfu}^{-1} \mathrm{~g}^{-1}$. One of the previous studies reported LAB counts range between $132 \times 10^{6}$ and $246 \times 10^{6} \mathrm{cfu} \cdot \mathrm{mL}^{-1}$ (Gandhi and Natrajan, 2010) in dahi of Indian origination. In this study, $59.38 \%$ of Lactobacilli, $21 \%$ of Streptococci, $8.2 \%$ Lactococci and $11.42 \%$ Leuconostocs were isolated from indigenous dahi of eastern Nepal (Figure 4). The population and microbial flora of LAB migh vary according to climatic condition of different regions. It is obvious that, there is high climatic and temperature variation between Himalayan area of eastern Nepal and southern hot climatic Indian terrain. In this scenario, our finding justifies the differences in microbiology of dahi from southern India and eastern Himalayan Nepal. Ultimately flavor dynamics, as flavor is important functions of microbes.

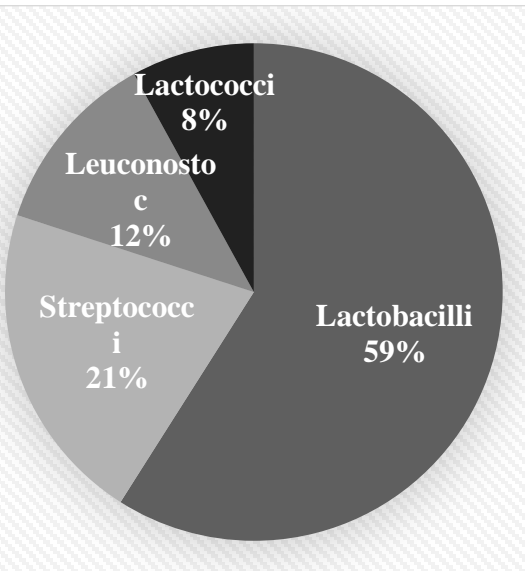

Figure 4 Distribution of LAB in indigenous dahi of eastern Nepal

\section{CONCLUSION}

This work showed a clear picture of microbial diversity and density in indigenous dahi of Nepal that might largely contribute to its typical texture and flavor. Dominant LAB comprising of Lactobacilli, Streptococci, Lactococci and Leuconostocs were successfully isolated from indigenous dahi. The wide diversity in microbial community could be attributed to variations in the specific environmental conditions found in Nepal as well as the manufacturing processes for indigenous dahi. Selection, propagation and preservation of the best performing strain to make starter culture could be done in future through genetic characterization. Further study on the volatile flavor compounds-matrix interactions, flavor release mechanisms, synergistic effect of flavor compounds and correlating these compounds to sensory attributes of indigenous dahi could be done. The profiles of volatile flavor compounds and unique role of indigenous fermentation strategy practiced could be elaborated in future.

Acknowledgments: The work is supported by Th-S\&T-069/070-51 university grant commision (UGC), Nepal. The funding agency had no role in study design, data collection and analysis. The authors would like to show gratitude to Basanta Raj Adhikari, Santosh Timilsina and Sudip Thagunna from Central campus of Technology, Dharan, Nepal for considerable help during sample collection, lab analysis and other technical aspects. Also, we would like to thank Parthivendra Upadhyaya from University of Bergen, Norway for going through text and commenting on the language.

\section{REFERENCES}

ABDALLA, M.O.M. AND HUSSAIN, S.I.K. 2010. Enumeration and identification of microflora in Roub, a Sudanese traditional fermented dairy product. British Journal of Dairy Sciences, 1(2), 30-33.

ABDELGADIR W. S., HAMAD, S. H., MØLLER, P. L., JAKOBSEN, M. 2001. Characterisation of the dominant microbiota of Sudanese fermented milk Rob. International Dairy Journal, 11 (1-2), 63-70. http://dx.doi.org/10.1016/s09586946(01)00042-5

AIRIDENGCAICIKE , CHEN X, DU X, WANG W, ZHANG J, SUN Z, LIU, W., LI, L., SUN, T., ZHANG, H. 2010. Isolation and identification of cultivable Lactic Acid Bacteria in traditional fermented milk of Tibet in China. International Journal of Dairy Technology, 63(3), 437-444. http://dx.doi.org/10.1111/j.1471-0307.2010.00595.x

AL RUBAYYI, K.A., ABD EL GAWAD, I.A. AND ABD EL FATAH, A.M 2010. Identification and characterization of dominant Lactic Acid Bacteria isolated from traditional Rayeb milk in Egypt. Journal of American Scinces, 6(10), 728-735.

ALI A. A. 2011. Isolation and identification of Lactic Acid Bacteria isolated from traditional drinking yoghurt in Khartoun State, Sudan. Current Research in Bacteriology, 4 (1), 16-22. http://dx.doi.org/10.3923/crb.2011.16.22

ATLAS, R.M. 2004. Handbook of Microbiological Media, Third edition. London: $\quad$ CRC Press $\quad$ ISBN 0-8493-1818-1. http://dx.doi.org/10.1201/9781420039726

AZADNIA, P., GHASEMI, M.S.A., MOHAGHEGH, M.D., JASHNI, M.K., ZAMANI, M.H., BABAKI, A.K., TAAROF, N. 2011. Isolation and identification of lactococci from traditional yoghurt in tribes of Kazerun. Journal of Animal and veterinary Advances, 10 (6), 698-700. http://dx.doi.org/10.3923/javaa.2011.698.700

BADIS, A., GUETAMI, D., MOUSSA-BOUDJEMA, B., HENNI, D.E. AND KIHAL, M. 2004a. Identification and technological properties of lactic acid bacteria isolated from raw goat milk of four Algerian races. Food Microbiology, 21(5), 579-588. http://dx.doi.org/10.1016/j.fm.2003.11.006

BADIS, A., GUETAMI, D., MOUSSA-BOUDJEMA, B., HENNI, D.E., TORNADIJO, M.E., KIHAL, M. 2004b. Identification of cultivable lactic acid bacteria isolated from Algerian raw goat's milk and evaluation of their technological properties. Food Microbiology, 21(3), 343-349. http://dx.doi.org/10.1016/s0740-0020(03)00072-8

BALDORJ, R., TUMENJARGAL, D. AND BATJARGAL B. (2003) Biochemical and microbiological study of fermented mare's milk (airag) prepared by traditional Mongolian technology. In Nomadic Cultural Traditions: Mongolian National Dairy Products, International Scientific Symposium Proceedings. pp. 70-76. Ulaanbaatar, Mongolia: The International Institute for the Study of Nomadic Civilizations, ISBN: 99929-5-789-1.

BEUKES E.M., BESTER B.H., MOSTERT J.F. 2001. The microbiology of South African traditional fermented milks. International Journal of Food Microbiol, 63(3), 189-197. http://dx.doi.org/10.1016/s0168-1605(00)00417-7

BHATTARAI R.R. AND DAS S.K.L. 2013. Scientific study on indigenous technology of dahi making of eastern Nepal. Journal of Food Processing and Technology, 4(8), 253. http://dx.doi.org/10.4172/2157-7110.1000253

CHAMMAS, G.I., SALIBA, R., CORRIEU, G., BEAL, C. 2006. Characterisation of lactic acid bacteria isolated from fermented milk "Laban". International Journal of Food Microbiology, 110(1), 52-61. http://dx.doi.org/10.1016/j.ijfoodmicro.2006.01.043

DEWAN S., TAMANG J.P. 2007. Dominant lactic acid bacteria and their technological properties isolated from the Himalayan ethnic fermented milk products. Antonie van Leeuwenhoek, 92(3), 343-352. http://dx.doi.org/10.1007/s10482-007-9163-5

GANDHI, D.N AND NATRAJAN, A.M. 2010. Preparation of a Good Quality Dahi (Curd) and Probiotic Milk Products. [Internet document]. URL http://s3-ap- 
southeast-2.amazonaws.com/jigsydney/general/PDF/49212 Dahi-Making.pdf Accessed January 2015.

GILLILAND, S.E. 1990. Health and nutritional benefits from lactic acid bacteria. FEMS Microbiology Reviews, 87, 175-188. http://dx.doi.org/10.1111/j.15746968.1990.tb04887.x

GRAN, H.M., GADAGA, H.T, NARVHUS, J.A. 2003. Utilisation of various starter cultures in the production of Amasi, a Zimbabwean naturally fermented raw milk product. International Journal of Food Microbiology, 88(1), 19-28. http://dx.doi.org/10.1016/s0168-1605(03)00078-3

ERKUS,, O. (2007). Isolation, Phenotypic and Genotypic Characterization of Yoghurt Starter Bacteria. A Thesis Submitted to the Graduate School of Engineering and Sciences of Izmir Institute of Technology in Partial Fulfillment of the Requirements for the Degree of Master of Science in Food Engineering. FRANCOIS, Z. N., EL HODA, N., FLORENCE F.A., PAUL, M.F., FELICITE, T.M. AND EL SODA, M. (2007). Biochemical Properties of Some Thermophilic Lactic Acid bacteria Strains from Traditional Fermented Milk Relevant to Their technological performance as Starter Culture. Biotechnol. 6(1):14-21.

HARRIGAN, W.F., MCCANCE, M.E. 1976. Laboratory Methods in Food and Dairy Microbiology. Revised Edition. New York : Academic Press.

HARUN-UR-RASHID, M., TOGO, K. AND UEDA, M. 2007. Identification and characterization of dominant lactic acid bacteria isolated from traditional fermented milk Dahi in Bangladesh. World Journal of Microbiology and Biotechnology, 23(1), 125-133. http://dx.doi.org/10.1007/s11274-006-9201-x

KEMPLER G. M., MCKAY L. L. 1980. Improved Medium for Detection of Citrate-Fermenting Streptococcus Lactis Subsp. Diacetylactis. Applied and Environmental Microbioliology, 39(4), 926-927.

KHAREL G.P., ACHARYA P.P., RAI B.K. 2010. Traditional Foods of Nepal. Kathmandu: Highland Publications.

KURMANN, J. A. 1984. The production of fermented milk in the world: aspects of the production of fermented milks. International Dairy Federation Bulletin, $179,16-26$.

MANOLOPOULOU, E., SARANTINOPOULOS, P., ZOIDOU, E., AKTYPIS A., MOSCHOPOULOU, E., KANDARAKIS, .I.G., ANIFANTAKIS, E.M 2003. Evolution of microbial populations during traditional Feta cheese manufacture and ripening. International Journal of Food Microbiology, 82(2), 153-161. http://dx.doi.org/10.1016/s0168-1605(02)00258-1

MATARAGAS, M., DROSINOS, E. H., TSAKALIDOU, E. METAXOPOULOS, J. 2004. Influence of nutrients on growth and bacteriocin production by Leuconostoc mesenteroides L124 and Lactobacillu curvatus L442. Antonie van Leeuwenhoek, 85(3), 191-198. http://dx.doi.org/10.1023/b:anto.0000020291.01957.a2

MATHARA, J.M., SCHILLINGER, U., KUTIMA, P.M., MBUGUA, S.K., HOLZAPFEL, W.H. 2004. Isolation, identification and characterization of the dominant microorganisms of kule naoto: the Maasai traditional fermented milk in Kenya. International Journal of Food Microbiology, 94(3), 269-278.

MATHOT, A, G., KIHAL, M., PREVOST, H., DIVIES, C. 1994. Selective enumeration of leuconostoc on Vancomycin agar media. International Dairy Journal, 4(5), 459-469. http://dx.doi.org/10.1016/0958-6946(94)90059-0

MAYEUX, J.V., SANDINE, W.W.E., ELLIKER, P.R. 1962. A selective medium for detecting leuconostoc organisms in mixed strain starter culture. Journal of Dairy Science, 45, 655-656.

MEHMOOD, T., MASUD, T., ALI ABBAS, S., MAQSUD, S. 2009. Isolation and identification of wild strains of lactic acid bacteria for yoghurt preparation from indigenous Dahi. Pakistan Journal of Nutrition, 8(6), 866-871. http://dx.doi.org/10.3923/pjn.2009.866.871

MUYANJA, C.M., NARVHUS, J.A., TREIMO, J., LANGSRUD, T. 2003 Isolation, characterisation and identification of lactic acid bacteria from bushera: a Ugandan traditional fermented beverage. International Journal of Food Microbiology, 80(3) 201-210. http://dx.doi.org/10.1016/s0168-1605(02)00148-4 NAWAZ M.A. AND BHATTARAI R.R. 2015. Isolation \& identification of Yersinia \& Pseudomonas sp. from Australian milk \& salad using 16s rDNA Peerj Preprints 3:e820v1. https://dx.doi.org/10.7287/peerj.preprints.820v1

OBODAI, M., DODD, C. 2005. Characterization of dominant microbiota of Ghanaian fermented milk products, nyarmie, by culture and non-culture-based methods. Journal of Applied Microbiology, 100(6), 1355-1363. http://dx.doi.org/10.1111/j.1365-2672.2006.02895.x

OKI, K., DUGERSUREN, J., DEMBEREL, S., WATANABE， K. 2014 Pyrosequencing analysis of microbial diversity of Airag, Khoormog and Tarag, traditional fermented dairy products of Mongolia. Bioscience of Microbiota, Food and Health, 33(2), 53-64. http://dx.doi.org/10.12938/bmfh.33.53

OLASUPO, N.A., SCHILLINGER, U., HOLZAPFEL, W.H. 2001. Studies on some technological properties of predominant lactic acid bacteria isolated from Nigerian fermented foods. Food Biotechnology, 15(3), 157-167. http://dx.doi.org/10.1081/fbt-100107627

OMAFUVBE, B. O., ENYIOHA, L.C. 2011. Phenotypic identification and technological properties of lactic acid bacteria isolated from selected commercial Nigerian bottled yoghurt. African Journal of Food Science, 5(6), 340-348.

PUBLIC HEALTH ENGLAND. 2014. Preparation of samples and dilutions, plating and sub-culture. Microbiology Services. Food, water and environmental microbiology standard method FNES26(F2); Version 1.
REDDY, M.S., VEDAMUTHU, E.R., WASHAM, C.J., REINBOLD, G.W 1969. Differential agar medium for separating streptococcus lactis and streptococcus cremoris1. Applied Microbiology, 18(5), 755-759.

SAMELIS, J., MAUROGENAKIS, F., METAXOPOULOS, J. 1994 Characterization of lactic acid bacteria isolated from naturally fermented Greek dry salami. International Journal of Food Microbiology, 23(2), 179-196 http://dx.doi.org/10.1016/0168-1605(94)90051-5

SAVADOGO, A., OUATTARA, T., SAVADOGO, P., OUATTARA, A. BARRO, N. AND TRAORE, A. 2004. Microorganisms Involved in Fulani Traditional Fermented Milk in Burkina Faso. Pakistan Journal of Nutrition, 3(2), 134-139. http://dx.doi.org/10.3923/pjn.2004.134.139

SHARPE, M.E. 1979. Identification of the Lactic Acid Bacteria. In: Identification Methods for Microbiologists, Skinner, F.A. and D.W. Lovelock (Eds.). London : Academic Press. 233-259 pp.

TSEROVSKA, L., STEFANOVA, S., YORDANOVA, T. 2002. Identification of lactic acid bacteria isolated from katyk, goat's milk and cheese. Journal of Culture Collection, 3, 48-52.

XIAO, H., CHEN, X., CHEN, M., TANG, S., ZHAO, X. AND HUAN, L. (2004). Bovicin HJ50, a novel lantibiotic produced by Streptococcus bovis HJ50. Microbiology, 150:103-108.

YAVUZDURMAZ, H. 2007. Isolation, characterization, determination of probiotic properties of Lactic Acid Bacteria from human milk. M.Sc. Thesis Izmir Institute of Technology. Available: http://library.iyte.edu.tr/tezler/master/gidamuh/T000712.pdf accessed December 2014.

YU J, WANG WH, MENGHE BLG, JIRI MT, WANG HM, LIU WJ, BAO QH, LV Q, ZHANG JC, WANG F, XU HY, SUN TS, ZHANG HP (2011) Diversity of lactic acid bacteria associated with traditional fermented dairy products in Mongolia. Journal of Dairy Science, 94:3229-3241

ZAMFIR, M., VANCANNEYT, M., MAKRAS, L., VANINGELGEM, F. LEFEBVRE, K., POT, B., SWINGS, J., DE VUYST, L. 2006. Biodiversity of Lactic Acid Bacteria in Romanian dairy products. Systematic and Applied Microbiology, 29(6), 487-495. http://dx.doi.org/10.1016/j.syapm.2005.10.002 